\title{
Are Non-Celiac Autoimmune Diseases Responsive to Gluten-Free Diet?
}

\author{
Aaron Lerner ${ }^{1,2}$, Ajay Ramesh ${ }^{1}$, Torsten Matthias ${ }^{2, *}$ \\ ${ }^{1}$ B. Rappaport School of Medicine, Technion-Israel Institute of Technology, Haifa, Israel \\ ${ }^{2}$ AESKU.KIPP Institute, Wendelsheim, Germany \\ *Corresponding author: matthias@aesku.com
}

\begin{abstract}
Genetic risk factors for autoimmune diseases are constantly discovered, however, environmental factors are laggingbehind and the precipitating events leading to development of autoimmune diseases remain enigmatic. Gluten is a well-established inducing nutrient in celiac disease and gluten withdrawal is the only current effective therapy. More and more studies have shown that non-celiac autoimmune diseases can partially respond to gluten free diet. The present editorial reviews those conditions and suggest multiple potential mechanisms that might operate in clinical amelioration of non-celiac autoimmune diseases.
\end{abstract}

Keywords: gluten free diet, autoimmune disease, gluten, nutrition, mechanisms, autoimmunity

Cite This Article: Aaron Lerner, Ajay Ramesh, and Torsten Matthias, "Are Non-Celiac Autoimmune Diseases Responsive to Gluten-Free Diet?” International Journal of Celiac Disease, vol. 5, no. 4 (2017): 164-167. doi: 10.12691/ijcd-5-4-6.

\section{Introduction}

It is well known that autoimmune diseases (ADs) have two major causative background: genetic and environmental $[1,2,3]$. Due to the fact that ADs incidence is markedly increased in the Western countries in the last decades [4,5], it is logical to assume that the surge is due to changing environment, much more than genetic modifications or adaptations. Taking into account that the worldwide wheat consumption and gluten intake are likewise increasing, in the last decades [6], it is tempting to speculate that a positive association exist between the two and the surge of ADs. There is no doubt that, at least for celiac disease (CD), the increase in prevalence is tightly relayed to the increased wheat consumption around the world [4,7]. Since CD is associated with multiple ADs, a question arises does gluten consumption contribute to the surge in the non-CD autoimmune conditions and if so, does gluten withdrawal might as well benefit the autoimmune affected populations.

In this regard, the case reported by the Iranian group on the positive effect of gluten-free diet (GFD) in refractory inflammatory bowel disease is very interesting [8] and brings up the topic of GFD in non-CD autoimmune condition. Rostami-Nejad et al. described a young male with refractory left-sided ulcerative colitis with normal bulbar and duodenal biopsies and CD associated serology. Upon GFD, his symptoms disappeared and the colonic pathology improved. It should be noted that other recent reports on Crohn's disease patients reported that GFD might be beneficial in reducing gastrointestinal symptoms, disease activity index and drug responsiveness [9,10,11]. The present editorial will review the non-CD ADs that under certain circumstances responded to GFD, and the potential mechanism relaying gluten withdrawal to the improvement of autoimmune diseases and their responsiveness.

\section{GFD in none Classical Gluten Dependent Autoimmune Conditions}

The subject of GFD in other peripheral, non-enteric ADs was reviewed in the past $[12,13]$ and most recently extensively described [14]. Interestingly, in a most recent editorial on the subject of indications for GFD, those nonCD, systemic ADs were not mentioned [15].

\section{Potential Mechanisms of Gluten Free Nutritional Therapy in Non-Enteric Autoimmune Diseases}

The list of all diseases in Table 1 is associated with CD and GFD [39] and multiple autoantibodies that are circulating in the patient's blood circulation [40]. Suspicions about the benefit of GFD as a complementary treatment, either as a causal factor in the pathogenesis, or improvement of symptoms, was raised and reviewed lately $[41,42]$.The fact that GFD have protective effects on the cumulative prevalence of additional autoimmune diseases in CD patients $[43,44]$, opens a window of opportunities to explore the topic of gluten as a driver of autoimmunity and the place of GFD in ADs dietary therapy.

Not less interesting are the potential pathways by which gluten withdrawal might impact the initiation and the progression of autoimmunity. Following are some of those potential mechanisms. 
a. Shared genes. CD shares HLA and various non-HLA genes with associated ADs [45,46,47,48].

b. Increases intestinal permeability and leaky gut induction. Various processed food ingredients and additives were proved or suspected to breach tight junction functional integrity [6,39].Gluten is one of them [6,49,50]. WillGFD attenuate the leaky gut process?

c. Microbiome/dysbiome imbalance. The dysbiotic repertoire related to animal models of specific ADs was recently summarized [3], and multiple publications exist on the dysbiosis in CD and other human ADs [39,51]. Gluten affects microbiome composition and diversity as shown in animal models and on humans [14,39]. Can gluten drive systemic autoimmunity through its effects on the human microbiome?

d. Pro-inflammatory and potentially auto immunogenic effects. Gluten is immunogenic, cytotoxic, pro-inflammatory and activates several immune pathways (including IL-17). It increases apoptosis, suppresses cell viability and differentiation, induces oxidative stress and affects epigenetic behavior [14].

e. Increased amount, toxicity and immunogenicity. Contemporary gluten has evolved tremendously since its discovery in the Fertile Crescent around 15000 years ago [2]. The wheat gluten content increased about 8 folds, its worldwide consumption expanded, its toxicity and immunogenicity rose and created a geoepidemiology. This dynamics paralleled the increased incidence of CD and other ADs [2,4,5,52,53]

f. Intestinal post translational modification of protein (PTMP) represents a key regulator in autoimmunity, by transforming naïve/self or non-self-peptides to auto immunogenic ones. [3,39,54]. Gluten is an ideal substrate for enzymatic PTMP, tissue and microbial transglutaminases being typical examples $[3,54,55,56]$.

g. Tissue and microbial transglutaminases are extensively distributed in the human body and intestinal lumen, respectively $[39,54,57]$. Human transglutaminase plays a role in end organ affected ADs. Autoimmune thyroiditis, rheumatoid arthritis, IgA nephropathy, dermatitis herpetiformis and gluten ataxia are some of the examples [58-63]. On the other hand, gluten/gliadin peptides are internalized systemically and are secreted in the human urine $[64,65]$, or appear in the mice pancreas following oral administration [66]. One wonders if in the absence of gluten, no immunogenic or neo-epitopes' complexes will be available to drive autoimmunity.

h. HLA-DQ2/8-restricted gluten specific $T$ cells have been observed to migrate from the intestinal lamina propria into peripheral blood upon gluten challenge, representing an additional mechanism for extraintestinal manifestations in $\mathrm{CD}$, or potentially reaching peripheral organs in other ADs and thus, ameliorated on GFD [67].

Table 1. Summarizes the peripheral/systemic AD sthat were described to partially respond to GFD

\begin{tabular}{|c|c|c|}
\hline Disease type & Improved Parameter & Reference \\
\hline Rheumatoid arthritis & $\begin{array}{l}\text { Clinical and joint ultrasound improvement } \\
\text { Atheroprotective and anti-inflammatory }\end{array}$ & $\begin{array}{l}{[16,17]} \\
{[18]}\end{array}$ \\
\hline Type 1 diabetes mellitus & $\begin{array}{l}\text { Preserve beta cell function } \\
\text { Improve insulin secretion } \\
\text { Lower HbA1c } \\
\text { Improved quality of life }\end{array}$ & $\begin{array}{l}{[19]} \\
{[20]} \\
{[21]} \\
{[22]}\end{array}$ \\
\hline Autoimmune thyroiditis & $\begin{array}{l}\text { Normalization of subclinical hypothyroidism } \\
\text { Decrease in anti-thyroid autoantibodies }\end{array}$ & {$[23]$} \\
\hline Autoimmune hepatitis & Treatment-free sustained remission & {$[25,26,27]$} \\
\hline Multiple sclerosis & Clinical improvement & {$[28,29,30]$} \\
\hline Psoriasis & $\begin{array}{l}\text { Clinical and severity indeximprovement, } \\
\text { Decrease the expression of CD associated antibodies }\end{array}$ & $\begin{array}{l}{[31-35]} \\
{[36,37]}\end{array}$ \\
\hline IBD & Clinical, pathological and disease activity improvement & {$[8,9,10,11]$} \\
\hline Vitiligo & Re-pigmentation & {$[38]$} \\
\hline
\end{tabular}

Non-celiac autoimmune diseases that partially respond to GFD. Adapted from ref [12,13,14].

\section{Conclusions}

We are far away from unraveling the mechanisms by which GFD can alleviate non-celiac ADs initiation or progression and there are more questions than answers on this very challenging topic.

\section{References}

[1] Lerner A, Blank M, Shoenfeld Y. Celiac disease and autoimmunity.Isr J Med Sci 1996; 32: 33-36.

[2] Lerner A. The last two millennias eco-catastrophes are the driving forces for the potential genetic advantage mechanisms in celiac disease. Med Hypotheses. 2011; 77: 773-6.

[3] Lerner A, Aminov R, Matthias T. Dysbiosis may trigger autoimmune diseases via inappropriate posttranslational modification of host proteins. Front in Microbiol.2016; 7: 84.

[4] Lerner A, Jermias P, Matthias T. The world incidence of celiac disease is increasing: a review. Internat. J. Of Recent Scient. Res. 2015; 7: 5491-5496.
[5] Lerner A, Jeremias P, Matthias T. The world incidence and prevalence of autoimmune diseases is increasing: A review. Internat J Celiac Disease. 2015; 3: 151-155.

[6] Lerner A, Matthias T. Changes in intestinal tight junction permeability associated with industrial food additives explain the rising incidence of autoimmune disease. Autoimmun Rev. 2015; 14: 479-89.

[7] Catassi C, Gatti S, Lionetti E. World perspective and celiac disease epidemiology. Dig Dis. 2015; 33: 141-6.

[8] Rostami-Nejad M, Sadeghi A, Asadzadeh-Aghdaei H, Rismantab S, Reza Zali M. Gluten-free Diet for Refractory Inflammatory Bowel Disease; A Case Report. Internatiol J of Celiac Dis. 2017, 5 168-170.

[9] Catassi C, Elli L, Bonaz B, Bouma G, Carroccio A, Castillejo G, et al. Diagnosis of Non-CeliacGluten Sensitivity (NCGS): The Salerno Experts' Criteria. Nutrients. 2015; 7: 4966-77.

[10] Aziz I, Pearson K, Priest J, Sanders D. A Study Evaluating the Bidirectional Relationship Between Inflammatory Bowel Disease and Self-reported Non-celiac Gluten Sensitivity. Inflamm Bowel Dis 2015; 21: 847-53.

[11] Hans H ,Christopher F, Robert S, Michael D, Millie D. Prevalence of a Gluten-free Diet and Improvement of Clinical Symptoms in Patients with Inflammatory Bowel Diseases. Inflamm Bowel Dis 2014; 20: 1194-7. 
[12] San Mauro Martín I, Garicano Vilar E, Collado Yurrutia L, Ciudad Cabañas MJ. [Is gluten the great etiopathogenic agent of disease in the XXI century?]. Nutricion Hospitalaria. 2014; 30: 1203-10.

[13] El-Chammas K, Danner E. Gluten-free diet in nonceliac disease. Nutr in Clin Pract 2011; 26: 294-9.

[14] Lerner A, Shoenfeld Y, Matthias T. Gluten; essential for wheat survival but detrimental to human health. Nutr Rev. In press. 2017.

[15] Rostami K, Bold J, Parr A, Johnson MW. Gluten-Free Diet Indications, Safety, Quality, Labels, and Challenges. Nutrients. 2017 Aug 8; 9(8). pii: E846.

[16] Hafström I, Ringertz B, Spångberg A, von Zweigbergk L, Brannemark S, Nylander I, Rönnelid J, Laasonen L, Klareskog L. A vegan diet free of gluten improves the signs and symptoms of rheumatoid arthritis: the effects on arthritis correlate with a reduction in antibodies to food antigens. Rheumatol (Oxford) 2001; 40: $1175-9$.

[17] Iagnocco A, Ceccarelli F, Mennini M, Rutigliano IM, Perricone C, Nenna R, et al. Subclinical synovitis detected by ultrasound in children affected by coeliac disease: a frequent manifestation improved by a gluten-free diet. Clin Exp Rheumatol. 2014; 32: 137-42.

[18] Elkan AC, Sjöberg B, Kolsrud B, Ringertz B, Hafström I Frostegård J. Gluten-free vegan diet induces decreased LDL and oxidized LDL levels and raised atheroprotective natural antibodies against phosphorylcholine in patients with rheumatoid arthritis: a randomized study. Arthr Res and Ther 2008; 10: R34-41.

[19] Antvorskov JC, Josefsen K, Engkilde K, Funda DP, Buschard K. Dietary gluten and the development of type 1 diabetes. Diabetologia. 2014; 57: 1770-80.

[20] Pastore MR, Bazzigaluppi E, Belloni C, Arcovio C, Bonifacio E, Bosi E. Six months of gluten-free diet do not influence autoantibody titers, but improve insulin secretion in subjects at high risk for type 1 diabetes. $\mathrm{J}$ of Clin Endocrinol and Metabol 2003; 88: 162-5.

[21] Svensson J, Sildorf SM, Pipper CB, Kyvsgaard JN, Bøjstrup J, Pociot FM, et al.Potential beneficial effects of a gluten-free diet in newly diagnosed children with type 1 diabetes: a pilot study.Springerplus. 2016; 5: 994.

[22] Pham-Short A, Donaghue KC, Ambler G, Garnett S, Craig ME. Quality of Life in Type 1 Diabetes and Celiac Disease: Role of the Gluten-Free Diet. J Pediatr. 2016; 179: 131-138. e1.

[23] Sategna-Guidetti C, Volta U, Ciacci C, Usai P, Carlino A, De Franceschi L, Camera A, Pelli A, Brossa C. Prevalence of thyroid disorders in untreated adult celiac disease patients and effect of gluten withdrawal: an Italian multicenter study. Amer $\mathrm{J}$ of Gastroenterol 2001; 96: 751-7.

[24] Toscano V, Conti FG, Anastasi E, Mariani P, Tiberti C, Poggi M, Montuori M, Monti S, Laureti S, Cipolletta E, et al. Importance of gluten in the induction of endocrine autoantibodies and organ dysfunction in adolescent celiac patients. Amer $\mathrm{J}$ of Gastroenterol 2000; 95: 1742-8.

[25] Nastasio S, Sciveres M, Riva S, Filippeschi IP, Vajro P, Maggiore G. Celiac disease-associated autoimmune hepatitis in childhood long-term response to treatment. J of Pediatr Gastroenterol and Nutr 2013; 56: 671-4.

[26] Colecchia A, Di Biase AR, Scaioli E, Festi D. Coeliac disease and autoimmune hepatitis: Gluten-free diet can influence liver disease outcome. Digest Liv Dis 2011; 43: 247-9.

[27] Iqbal U, Chaudhary A, Karim MA, Siddiqui MA, Anwar H, Merrell N. Association of Autoimmune Hepatitis and Celiac Disease: Role of Gluten-Free Diet in Reversing Liver Dysfunction. J Investig Med High Impact Case Rep. 2017; 5: 2324709617705679.

[28] Rodrigo L, Hernández-Lahoz C, Fuentes D, Alvarez N, LópezVázquez A, González S. Prevalence of celiac disease in multiple sclerosis. BMC Neurol2011; 11: 31-7.

[29] Finsterer J, Leutmezer F. Celiac disease with cerebral and peripheral nerve involvement mimicking multiple sclerosis. $\mathrm{J}$ of Med Life. 2014; 7: 440-4.

[30] von Geldern G, Mowry EM. The influence of nutritional factors on the prognosis of multiple sclerosis. Nat Rev Neurol 2012; 8: 678-89.

[31] Michaëlsson G, Gerdén B, Hagforsen E, Nilsson B, Pihl-Lundin I, Kraaz W, Hjelmquist G, Lööf L. Psoriasis patients with antibodies to gliadin can be improved by a gluten-free diet. Brit $\mathrm{J}$ of Dermatol 2000; 142: 44-51.
[32] Addolorato G, Parente A, de Lorenzi G, D’angelo Di Paola ME, Abenavoli L, Leggio L, Capristo E, De Simone C, Rotoli M, Rapaccini GL, et al. Rapid regression of psoriasis in a coeliac patient after gluten-free diet. A case report and review of the literature. Digest 2003; 68: 9-12.

[33] Frikha F, Snoussi M, Bahloul Z. Osteomalacia associated with cutaneous psoriasis as the presenting feature of coeliac disease: case report. Pan Afr Med J 2012; 11: 58.

[34] De Boer WA, Tytgat GN. A patient with osteomalacia as single presenting symptom of gluten-sensitive enteropathy. $\mathrm{J}$ of Intern Med 1992; 232: 81-5.

[35] Afifi L, Danesh MJ, Lee KM, Beroukhim K, Farahnik B, Ahn RS, et al. Dietary Behaviors in Psoriasis: Patient-Reported Outcomes from a U.S. National Survey. Dermatol Ther (Heidelb). 2017; 7: 227-242.

[36] Michaëlsson G, Ahs S, Hammarström I, Lundin IP, Hagforsen E. Gluten-free diet in psoriasis patients with antibodies to gliadin results in decreased expression of tissue transglutaminase and fewer Ki67+ cells in the dermis. Acta Dermato- Venereologica. 2003; 83: 425-9.

[37] D'Erme AM, Kovacikova Curkova A, Agnoletti AF, Milanesi N, Simonacci F et al. Gluten-free diet as a therapeutic approach in psoriatic patients: if yes, when. G Ital Dermatol Venereol. 2015; 150: 317-20.

[38] Khandalavala BN, Nirmalraj MC. Rapid partial repigmentation of vitiligo in a young female adult with a gluten-free diet. Case Rep Dermatol. 2014; 6: 283-7.

[39] Lerner A, Matthias T. Extraintestinal manifestations of CD: Common pathways in the gut-remote organs' axes. Internat $\mathrm{J}$ Celiac Dis. 2017; 5: 24-27.

[40] Shaoul R. Lerner A. Associated autoantibodies in celiac disease. Autoimmun. Rev. 2007; 6: 559-565.

[41] San Mauro Martín I, Garicano Vilar E, Collado Yurrutia L, Ciudad Cabañas MJ. [Is gluten the great etiopathogenic agent of disease in the XXI century?]. Nutricion Hospitalaria. 2014; 30: 1203-10.

[42] El-Chammas K, Danner E. Gluten-free diet in nonceliac disease. Nutr in Clin Pract 2011; 26: 294-9.

[43] Cosnes J, Cellier C, Viola S, Colombel JF, Michaud L, Sarles J, Hugot JP, Ginies JL, Dabadie A, Mouterde O, et al. Incidence of autoimmune diseases in celiac disease: protective effect of the gluten-free diet. Clin Gastroenterol and Hepatol 2008; 6: 753-8.

[44] Ferretti G, Bacchetti T, Masciangelo S, Saturni L. Celiac disease, inflammation and oxidative damage: a nutrigenetic approach. Nutrients 2012; 4: 243-57.

[45] Richard-Miceli C, Criswell LA. Emerging patterns of genetic overlap across autoimmune disorders. Genome Med 2014; 4: 6-14.

[46] Gutierrez-Achury J, Coutinho de Almeida R, Wijmenga C. Shared genetics in coeliac disease and other immune-mediated diseases. $\mathrm{J}$ of Internl Med 2011; 269: 591-603.

[47] Fortune MD, Guo H, Burren O, Schofield E, Walker NM, Ban M, Sawcer SJ, Bowes J, Worthington J, Barton A, et al. Statistical colocalization of genetic risk variants for related autoimmune diseases in the context of common controls. Nat Genet 2015; 47: 839-46.

[48] Lundin KE, Wijmenga C. Coeliac disease and autoimmune disease-genetic overlap and screening.Nat Rev Gastroenterol Hepatol. 2015; 12: 507-15.

[49] Fasano A. Leaky gut and autoimmune diseases. Clin Rev Allergy Immunol. 2012; 42: 71-78.

[50] Hollon J, Puppa EL, Greenwald B, Goldberg E, Guerrerio A, Fasano A. Effect of gliadin on permeability of intestinal biopsy explants from celiac disease patients and patients with non-celiac gluten sensitivity. Nutrients. 2015; 7: 1565-1576.

[51] Wu,HJ, Wu,E. The role of gut microbiota in immune homeostasis and autoimmunity. Gut Microbes. 2012; 3, 4-14.

[52] Manzel A, Muller DN, Hafler DA, Erdman SE, Linker RA, et al Role of "Western diet" in inflammatory autoimmune diseases. Curr Allergy Asthma Rep 2014; 14: 404.

[53] Selmi C, Tsuneyama K. Nutrition, geoepidemiology, and autoimmunity. Autoimmun Rev. 2010; 9: A267-270.

[54] Lerner A, Aminov R, Matthias T. Intestinal dysbiotic transglutaminases are potential environmental drivers of systemic autoimmunogenesis. Frontiers in Microbiology, 2017; 8; article 66

[55] Lerner A, Matthias T. Possible association between celiac disease and bacterial transglutaminase in food processing: a hypothesis. Nutr Rev. 2015; 73: 544-552. 
[56] Matthias T, Jeremias P, Neidhöfer S, Lerner A. The industrial food additive microbial transglutaminase, mimics the tissue transglutaminase and is immunogenic in celiac disease patients. Autoimmun Rev, 2016; 15: 1111-1119.

[57] Lerner A, Neidhöfer S, Matthias T. Transglutaminase 2 and anti transglutaminase 2 autoantibodies in celiac disease and beyond: Part A: TG2 double-edged sword: gut and extraintestinal involvement. Immunome Research, 2015; 11: 101-105.

[58] Lerner A, Jeremias P, Matthias T. The gut-thyroid axis and celiac disease. Endocrinol Cennections, 2017: 6: R52-R58.

[59] Lerner A, Matthias T. Rheumatoid arthritis-celiac disease relationship: joints get that gut feeling. Autoimm Rev. 2015: 14: 1038-47.

[60] Lerner A, Neidhöfer S, Matthias T. Beyond the joint: what's happening in the gut. Internat J Celiac Dis. 2016; 4: 127-129.

[61] Lerner A, Berthelot L, Jeremias P, Abbad L, Matthias T, Monteiro RC.. Gut-kidney axis: gluten, transglutaminase, celiac disease and IgA nephropathy JCCI, 2017; 8: 499-503.

[62] Reunala T, Salmi TT, Hervonen K. Dermatitis herpetiformis: pathognomonic transglutaminase IgA deposits in the skin and excellent prognosis on a gluten-free diet. Acta Derm Venereol. 2015; 95: 917-22.
[63] Hadjivassiliou M, Mäki M, Sanders DS, Williamson CA, Grünewald RA, Woodroofe NM, Korponay-Szabó IR. Autoantibody targeting of brain and intestinal transglutaminase in gluten ataxia. Neurology. 2006; 66: 373-7.

[64] Moreno ML, Cebolla Á, Muñoz-Suano A, Carrillo-Carrion C, Comino I, Pizarro Á, et al. Detection of gluten immunogenic peptides in the urine of patients with coeliac disease reveals transgressions in the gluten-free diet and incomplete mucosal healing. Gut. 2017; 66: 250-257.

[65] Moreno ML, Rodríguez-Herrera A, Sousa C, Comino I.Biomarkers to Monitor Gluten-Free Diet Compliance in Celiac Patients.Nutrients. 2017 Jan 6; 9(1). pii: E46.

[66] Bruun SW, Josefsen K, Tanassi JT, Marek A, Pedersen MH, Sidenius U, et al. Large Gliadin Peptides Detected in the Pancreas of NOD and Healthy Mice following Oral Administration. J Diabetes Res. 2016; 2016: 2424306.

[67] Ráki M, Fallang LE, Brottveit M, Bergseng E, Quarsten H, Lundin KE, Sollid LM. Tetramer visualization of gut-homing glutenspecific $\mathrm{T}$ cells in the peripheral blood of celiac disease patients. Proc Natl Acad Sci U S A. 2007; 104: 2831-6. 